\title{
On Concealed Questions
}

\author{
Maribel Romero \\ University of Pennsylvania
}

\section{Introduction}

The underlined Nouns Phrases (NPs) in (1) have been called 'Concealed Questions' (CQ, henceforth) because sentences that embed them typically have the same truth-conditional meaning as the corresponding versions with a fullfledged embedded interrogative clause, as illustrated in (2) (Heim 1979):

a. John knows the price of milk.

b. They announced the winner of the contest.

c. The temperature of the lake depends on the season.

(2) a. John knows how much the milk costs.

b. They announced who won the contest.

c. How warm the lake is depends on what season it is.

The goal of this talk is to review three main approaches to CQs in the literature -the pragmatic account, the individual concept account and the propositional account-, and to evaluate them with respect to several empirical patterns. The comparison across different data sets will lead to some conclusions and some important open questions, helping characterize the state of the art of the CQ debate in the literature.

Three main approaches to CQs will be discussed. The first one is the pragmatic approach in Heim (1979), in which [ kknow]] combines with an object of type e. For example, in (1a) [[know] would combine with the dollar amount (or degree on a scale) provided by the NP the price of milk. The second approach is the individual concept approach (Lasersohn 2005, Romero 2005a, among others). In this case, [ [know]] in (1a) would combine with an object of type $<\mathrm{s}, \mathrm{e}>$ provided by the NP the price of milk. Finally, in the propositional approach (Romero 2005b, Nathan 2005), [[know]] would combine with an object of type $<\mathrm{s}, \mathrm{t}>$ (or type $<\mathrm{s},<\mathrm{s}, \mathrm{t}>>$ ) arising from the NP the price of milk in (1a).

As we evaluate these approaches, we will examine the following five empirical patterns:

I would like to thank Ilaira Frana, Irene Heim, Lance Nathan, Arnim von Stechow and Hubert Truckenbrodt for stimulating conversations on different aspects of this paper. The many remaining errors are mine. 
(i) Simple concealed questions like the ones in (1).

(ii) Coordination of different types of verbs sharing the same NP complement.

(iii) Heim's (1979) ambiguity with nested concealed questions, illustrated in (3). Under a first reading -reading A in (4)-, (3) says that John knows the same price as Fred knows, e.g., they both know how much the milk costs. Under a second reading -reading B in (5)-, (3) asserts that John knows what price Fred knows. For example, this second reading would be true if Fred knows how much the milk costs and John knows that Fred knows how much the milk costs. Note that -assuming e.g. that the unique (relevant) price that Fred knows is the price of milk- reading A requires John to know how much the milk costs but reading $B$ does not.

(3) John knows the price that Fred knows.

(4) Reading A: "John knows the same price that Fred knows."

(5) Reading B: "John knows what price Fred knows.”

(iv) Gupta's syllogism. The verbs rise, fall and change have been argued to combine with individual concepts in sentences like (6) (Montague 1974, Dowty, Wall and Peters 1981, Lasersohn 2005). As we will see, Montague's analysis of (6) faces a problem with the syllogism in (7): the analysis predicts the argument to be invalid even though it is intuitively valid (Dowty, Wall and Peters 1981, citing Gupta):

(6) a. The temperature of the lake is rising / falling.

b. The price of milk changes every week.

(7) Gupta's syllogism:

i. Necessarily, the temperature is the price.

ii. The temperature is rising / changed.

iii. The price is rising / changed.

(v) Difference between NPs with rise / fall / change and NPs with know. Although NPs with rise / fall / change and NPs with know have been all analyzed as contributing an individual concept, important empirical differences remain between the two types. This is illustrated in (8). The NP the picture on Jordan's wall seems to provide the right type of argument for changes but not for know.

(8) A: John says he visits his niece Jordan with some frequency, but when I asked him what picture she has on her wall, he had no idea. 
B: The picture on Jordan's wall changes every month. \#That's why John didn't know the picture on Jordan's wall.

(Nathan 2005:59)

The paper is organized as follows. Section 2 examines the pragmatic account. Section 3 evaluates the individual concept account. Section 3 takes us to the propositional account. Section 5 summarizes the conclusions and points at some important open questions.

\section{Pragmatic Account}

Heim's (1979) tentatively proposes a pragmatic account for simple CQs. Know has two internal arguments: an individual argument of type e, provided by the extension of the NP, and a property argument $\mathrm{P}$ of type $<\mathrm{e}, \mathrm{st}>$, contextually provided. Under this account, (9a) is translated as in (9b). For the property argument $\mathrm{P}$, there is a strong pragmatic principle that makes $\mathrm{P}$ default to the property mentioned in the NP. Under the influence of this principle, the property $\mathrm{P}$ in (9b) would be resolved as in (9c).
a. John knows the capital of Italy.
b. $\lambda w$. know (j, $\mathrm{xx}_{\mathrm{e}}[$ capital-of-Italy(x,w)], P, w)
c. "John knows Rome as having the property P", where $\mathrm{P}$ is pragmatically resolved to "being the capital of Italy".

Heim makes the point that this pragmatic bias is not mandatory, that is, that $\mathrm{P}$ sometimes gets a value different from the property mentioned in the NP. For example, (10b) could be resolved as in (10c), as the sentence (10a) is true in scenario (11).

(10) a. John knows the most ridiculous price of the store (: the price of milk).

b. $\lambda w$. know ( $\mathrm{j}, \mathrm{xx}_{\mathrm{e}}[$ most-ridiculous-price $\left.(\mathrm{x}, \mathrm{w})], \mathrm{P}, \mathrm{w}\right)$

c. "John knows the actual most ridiculous price of the store -e.g., \$1.99as having the property P”, where P is pragmatically resolved to "being the price of milk".

(11) Scenario: John knows how much the milk costs at the store, in particular, he knows that the milk costs $\$ 1.99$. John knows no other price. As it turns out, the most ridiculously priced object in the store is the milk. John is not aware of the ridiculous character of this pricing.

The assumption that the NP denotes an individual of type e and that the pragmatic $\mathrm{P}$ can in principle be resolved to a contextually salient property faces several problems.

First, as noted in Romero (2005a), if the value of P can sometimes arise contextually, then (12) should be able to mean "John knows Rome as being the 
capital of Italy" when placed in the right context. This is contrary to fact: no matter how much one plays with the context, (12) does not have a CQ reading. ${ }^{1}$

\section{\# John knows Rome.}

The second problem concerns coordination. If all that the CQ NP really needs to contribute is an individual $\mathrm{x}_{\mathrm{e}}$, then, regardless of how the value for $\mathrm{P}$ is achieved, we would expect that the NP can be shared in a coordination structure involving a regular extensional verb and a CQ verb. This is contrary to fact, as shown in (13). ${ }^{2}$

a. \# Sam told me, and Kim actually visited, the capital of Vermont. (Nathan 2005)

b. \# John guessed and kissed the winner of the oscar for best actress. (Romero 2004)

Third and finally, Heim's (1979) ambiguity for nested concealed questions cannot be derived in this approach (Romero 2005a). To see this, consider example (3), repeated as (14), and the truth conditions (15) that this approach assigns to it.

(14) John knows the price that Fred knows.

(15) $\lambda w$. know $\left(j, \mathrm{x}_{\mathrm{e}}\left[\operatorname{price}(\mathrm{x}, \mathrm{w}) \wedge \operatorname{know}\left(\mathrm{f}, \mathrm{x}_{\mathrm{e}}, \mathrm{Q}, \mathrm{w}\right)\right], \mathrm{P}, \mathrm{w}\right)$

Assuming that Fred knows how much the milk costs and that the milk costs $\$ 1.99$, we can derive reading A using the values for P and Q in (16). This will give us the paraphrase "John knows as the price of milk the dollar amount $\mathrm{x}_{\mathrm{e}}$ that Fred knows as the price of milk". This is truth conditionally equivalent to reading A: "John knows the same price that Fred knows."

$$
\begin{array}{ll}
\mathrm{X}_{\mathrm{e}} & =\$ 1.99 \\
\mathrm{Q} & =\text { "being the price of milk" } \\
\mathrm{lX}_{\mathrm{e}}[\operatorname{price}(\mathrm{x}, \mathrm{w}) \wedge \operatorname{know}(\mathrm{f}, \mathrm{x}, \mathrm{Q}, \mathrm{w})] & =\$ 1.99 \\
\mathrm{P} & =\text { "being the price of milk" }
\end{array}
$$

For reading $B$, the closest that we can get to it in this approach is (17). The resulting paraphrase will be "John knows as having the property $\mathrm{P}$ the dollar amount $\mathrm{x}_{\mathrm{e}}$ that Fred knows as the price of milk", where $\mathrm{P}$ is the property "being the (dollar) value of the price that Fred knows”.

\footnotetext{
${ }^{1}$ In languages like Spanish in which epistemic 'know' and acquaintance 'know' are lexically distinct, the epistemic version of (12) is simply ungrammatical:

(i) * Juan sabe Roma. Juan knows Epi $^{\text {Rome }}$ 'John knows Epi Rome.'

${ }^{2}$ See also anaphora data in Romero (2004:§3.1) and Nathan (2005).
} 


$$
\begin{array}{ll}
\mathrm{X}_{\mathrm{e}} & \\
\mathrm{Q} & \$ 1.99 \\
\mathrm{~lx} & \text { "being the price of milk" } \\
\mathrm{P} & \$ 1.99 \\
= & \text { "being the dollar value of the price } \\
& \text { that Fred knows" }
\end{array}
$$

But, though close, this is not reading B. (17) requires that John knows $\$ 1.99$ as having the property "being the value of the price that Fred knows". Reading B namely, "John knows what price Fred knows"- does not require that John knows $\$ 1.99$ as the value of the price Fred knows.

Given the shortcomings of this pragmatic approach, we abandon it and move to other alternatives. ${ }^{3}$

\section{Individual Concept Account}

Heim (1979) entertains and Romero’s (2005a) further develops an individual concept (IC) approach to CQs. In this approach, know $w_{+\mathrm{CQ}}$ is an intensional verb taking as its internal semantic argument an intensional object of type $<\mathrm{s}$, $\mathrm{e}$, or of type $<$ s, $<$ s,e $>>$, etc., resulting in the crosscategorial lexical entry in (18):

$$
\begin{array}{r}
{[[k n o w+C Q]]=\quad \lambda y_{\tau} \lambda \mathrm{x}_{\mathrm{e}} \lambda \mathrm{w} . \forall \mathrm{w}^{\prime} \in \operatorname{Dox}_{\mathrm{x}}(\mathrm{w})\left[\mathrm{y}\left(\mathrm{w}^{\prime}\right)=\mathrm{y}(\mathrm{w})\right],} \\
\text { where } \tau=<\mathrm{s}, \mathrm{e}>\text { or }<\mathrm{s},<\mathrm{s}, \mathrm{e}>>\text { or... }
\end{array}
$$

This applies to a simple example like (9a), repeated as (20a), as follows. The complement NP the capital of Italy must provide an intensional object, in this case the individual concept in (19), that is, the intension of the NP. This intensional object fills the argument $\mathrm{y}_{\tau}$ of know. The resulting truth conditions for the sentence are in (20b).

Semantic contribution of the CQ the capital of Italy: $\lambda w^{\prime \prime} . \mathrm{tx}_{\mathrm{e}}$ [capital-of-Italy(x,w”)]

\footnotetext{
${ }^{3}$ A different pragmatic account of CQs is developed in Frana (2006, this volume). Although I have not seen the finished version of that paper, the key idea is to extend Kratzer's (2002) treatment of $k n o w_{+C P}$ to $k n o w_{+C Q}$. Instead of combining [ $\left[k n o w_{+C P} \rrbracket\right.$ with a proposition, [know $\left.w_{+C P} \rrbracket\right]$ combines with a fact pragmatically provided and with the proposition contributed by the CP. In the same vein, [know $w_{+\mathrm{CQ}} \rrbracket$ would combine not with an individual concept, but with an object $\mathrm{x}_{\tau}$ pragmatically provided and with a property of objects of type $\tau$ contributed by the NP. This promising approach may be able to avoid the shortcomings of the pragmatic approach discussed in the text and inherit some of the advantages that we will discuss for the individual concept approach. Furthermore, it allows for an elegant treatment of indefinite CQs. (For comparison, see the treatment of indefinite CQs in the propositional approach in the appendix at the end of the present paper.) A closer look at Frana's approach is left for future research.
} 
(20)

a. John knows the capital of Italy

b. $\lambda w \cdot \forall w^{\prime} \in \operatorname{Dox}_{\mathrm{j}}(\mathrm{w})$

$\left[\lambda w^{\prime \prime} \cdot 1 x_{e}\left[\right.\right.$ cap-of-Italy $\left.\left(x, w^{\prime \prime}\right)\right]\left(w^{\prime}\right)=\lambda w^{\prime \prime} \cdot 1 x_{e}\left[\right.$ cap-of-Italy $\left.\left.\left(x, w^{\prime \prime}\right)\right](w)\right]$

$=\lambda \mathrm{w} \cdot \forall \mathrm{w}^{\prime} \in \operatorname{Dox}_{\mathrm{j}}(\mathrm{w})$

$\left[1 x_{e}\left[\right.\right.$ capital-of-Italy $\left.\left(\mathrm{x}, \mathrm{w}^{\prime}\right)\right]=\mathrm{ix}_{\mathrm{e}}[$ capital-of-Italy $\left.(\mathrm{x}, \mathrm{w})]\right]$

Romero (2005a) notes that, in general, the intensional argument needed for a (de dicto attitude reading of) regular intensional verbs like look for can be drawn not just from the intension of the complement NP, but also from its extension. This is illustrated in (21)-(22). In (21), look for takes as its semantic argument the INTENSION of the NP the unicorn with the longest horn. In (22), look for takes as its semantic argument the EXTENSION of the NP, which is an intensional object itself. This yields the reading (22a), in which John is in a de dicto search in relation to the individual concept -e.g., $\lambda w$ ". $1 x_{\mathrm{e}}$ [unicorn-withlongest-horn(x,w”)]- that the NP the unicorn Fred is looking for refers to in the actual world.

(21) John is looking for the unicorn with the longest horn.

a. 'In all of John's bouletic alternatives w' in w: John finds in w' the individual that is the unicorn with the longest horn in w' (whichever that may be).'

(22) John is looking for the unicorn Fred is looking for (: the one with the longest horn.)

a. 'Each $x$ out of John and Fred is such that, in all of x's bouletic alternatives $\mathrm{w}^{\prime}$ in $\mathrm{w}$ : $\mathrm{x}$ finds in $\mathrm{w}^{\prime}$ the individual that is the unicorn with the longest horn in w' (whichever that may be).'

The freedom to choose the intension or the extension of the complement $\mathrm{NP}$-as long as the result is a intensional object of the right type- is, according to Romero (2005a), the source of the ambiguity between reading A and reading B in nested CQ examples. Reading A of (23) arises when matrix know takes as its semantic argument the extension of the complement NP. Reading B arises when matrix know takes the intension of the NP instead.

(23) John knows the price that Fred knows.

a. Reading A: $\left[\left[k n o w_{+\mathrm{CQ}}\right]\right]+$ EXTENSION of the price that Fred knows.

b. Reading B: [[know+CQ $\rrbracket+$ INTENSION of the price that Fred knows. 
The semantic computation of the complement NP the price that Fred knows is spelled out in (24). ${ }^{4}$ The top line in (24) gives us the intension of the entire NP.

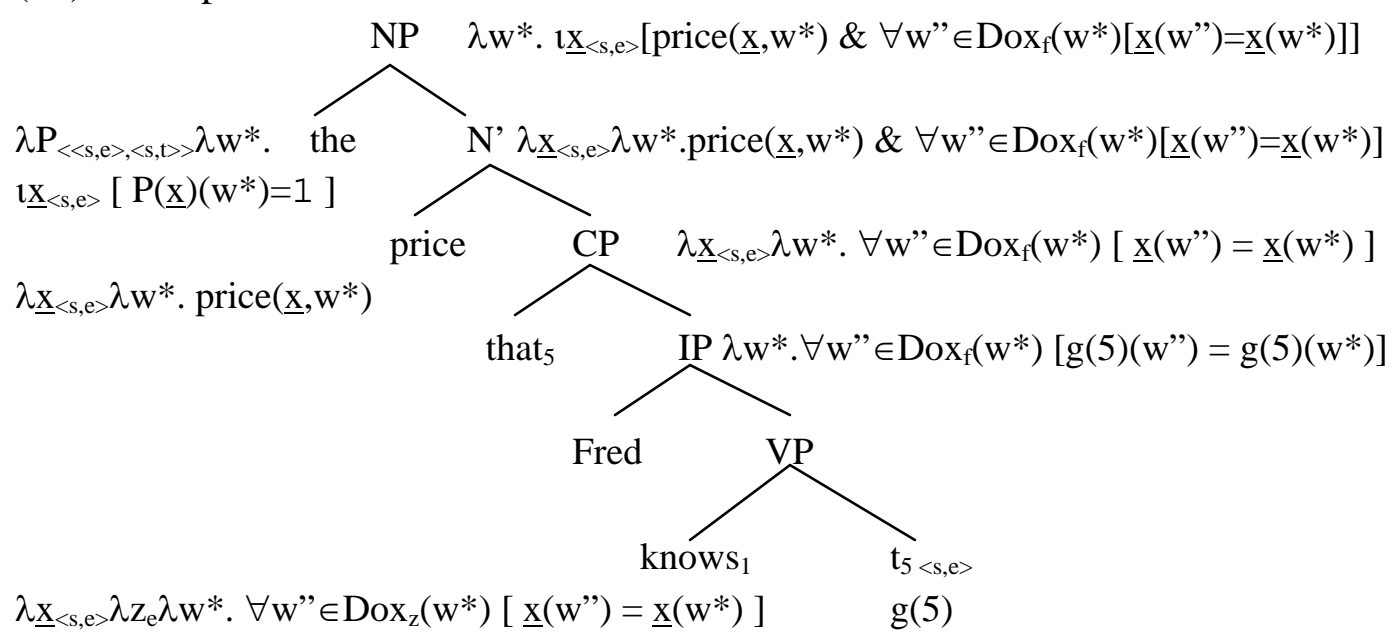

To derive reading $A$, we apply the intension in the top line in (24) to a given world $\mathrm{w}$ in (25a) to obtain the corresponding extension, and we feed the resulting object (of type $<$ s,e $>$ ) into the argument slot of [[know]]. The resulting truth conditions in (25b) correspond to reading A:

\section{(25) Reading A:}

a. Extension of the NP in $\mathrm{w}^{5}$

$$
\underline{\underline{x}}<\mathrm{s}, \mathrm{e}>\left[\operatorname{price}(\underline{\mathrm{x}}, \mathrm{w}) \& \forall \mathrm{w}, \in \operatorname{Dox}_{\mathrm{f}}(\mathrm{w})[\underline{\mathrm{x}}(\mathrm{w},)=\underline{\mathrm{x}}(\mathrm{w})]\right]
$$

b. Know+CQ + extension of the NP:

$\lambda w . \forall w^{\prime} \in \operatorname{Dox}_{\mathrm{j}}(\mathrm{w})$

$$
\begin{array}{r}
{\left[\underline{\mathrm{l}}<<\mathrm{s}, \mathrm{e}>\left[\operatorname{price}(\underline{\mathrm{x}}, \mathrm{w}) \& \forall \mathrm{w}, \in \operatorname{Dox}_{\mathrm{f}}(\mathrm{w})[\underline{\mathrm{x}}(\mathrm{w},)=\underline{\mathrm{x}}(\mathrm{w})]\right] \quad\left(\mathrm{w}^{\prime}\right)=\right.} \\
\left.\underline{\mathrm{x}}<\mathrm{s,e},\left[\operatorname{price}(\underline{\mathrm{x}}, \mathrm{w}) \& \forall \mathrm{w}^{\prime \prime} \in \operatorname{Dox}_{\mathrm{f}}(\mathrm{w})[\underline{\mathrm{x}}(\mathrm{w},)=\underline{\mathrm{x}}(\mathrm{w})]\right] \quad(\mathrm{w})\right]
\end{array}
$$

To derive reading $\mathrm{B}$, the NP's intension (of type $<\mathrm{s},<\mathrm{s}, \mathrm{e}>>$ ) is directly taken as the semantic argument of [[know]] in (26). The final truth conditions in (26c) match reading B:

\footnotetext{
${ }^{4}$ Since [[that ${ }_{5}$ Fred knows $t_{5} \rrbracket$ is a property of individual concepts (type $<<$ se $>$, $<$ st $>>$ ), the head noun price in the tree is assigned an intension of this type as well, so that (the intensional version of) the Predicate Modification Rule from Heim and Kratzer (1998) can apply between the two. That is, the intension of the lexical entry price in the tree (24) is a property of individual concepts (and not a property of individuals).

${ }^{5}$ I use explicit world indexing of the entire NP (though I could have as well used free world indexing of each predicate within it). See Cresswell (1990), Farkas (1993) and Percus (2000) for the empirical need of local and non-local world evaluation of NP predicates. For formal details, see Gallin (1975) for the formal Ty2 language and Percus (2000) for the syntax-semantics interface.
} 


\section{Reading B:}

a. Intension of the NP:

$\left.\lambda \mathrm{w}^{*} . \underline{\mathrm{x}}<\mathrm{s,e}, \mathrm{price}\left(\underline{\mathrm{x}}, \mathrm{w}^{*}\right) \& \forall \mathrm{w}^{\prime \prime} \in \operatorname{Dox}_{\mathrm{f}}\left(\mathrm{w}^{*}\right)\left[\underline{\mathrm{x}}\left(\mathrm{w}^{\prime \prime}\right)=\underline{\mathrm{x}}\left(\mathrm{w}^{*}\right)\right]\right]$

b. Know ${ }_{+\mathrm{CQ}}+$ intension of the NP:

$\lambda \mathrm{w} . \forall \mathrm{w}^{\prime} \in \operatorname{Dox}_{\mathrm{j}}(\mathrm{w})$

$\left[\lambda \mathrm{w}^{*} . \underline{\mathrm{x}_{<\mathrm{s}, \mathrm{e}}}\left[\operatorname{price}\left(\underline{\mathrm{x}}, \mathrm{w}^{*}\right) \& \forall \mathrm{w}^{\prime \prime} \in \operatorname{Dox}_{\mathrm{f}}\left(\mathrm{w}^{*}\right)\left[\underline{\mathrm{x}}\left(\mathrm{w}^{\prime \prime}\right)=\underline{\mathrm{x}}\left(\mathrm{w}^{*}\right)\right]\right]\left(\mathrm{w}^{\prime}\right)=\right.$ $\left.\lambda \mathrm{w}^{*} . \underline{\mathrm{x}}<\mathrm{s, \textrm {e }}>\left[\operatorname{price}\left(\underline{\mathrm{x}}, \mathrm{w}^{*}\right) \& \forall \mathrm{w}^{\prime \prime} \in \operatorname{Dox}_{\mathrm{f}}\left(\mathrm{w}^{*}\right)\left[\underline{\mathrm{x}}\left(\mathrm{w}^{\prime \prime}\right)=\underline{\mathrm{x}}\left(\mathrm{w}^{*}\right)\right]\right](\mathrm{w}) \quad\right]$

c. Simplification:

$\lambda \mathrm{w} . \forall \mathrm{w}^{\prime} \in \operatorname{Dox}_{\mathrm{j}}(\mathrm{w})$

$\left[\underline{\underline{\mathrm{X}}} \underline{\mathrm{s} s, \mathrm{e}}_{\mathrm{w}}\left[\operatorname{price}\left(\underline{\mathrm{x}}, \mathrm{w}^{\prime}\right) \& \forall \mathrm{w}^{\prime \prime} \in \operatorname{Dox}_{\mathrm{f}}\left(\mathrm{w}^{\prime}\right)\left[\underline{\mathrm{x}}\left(\mathrm{w}^{\prime \prime}\right)=\underline{\mathrm{x}}\left(\mathrm{w}^{\prime}\right)\right]\right]=\right.$ $\left.\underline{\underline{X}}<s, e>\left[\operatorname{price}(\underline{x}, w) \& \forall w^{\prime \prime} \in \operatorname{Dox}_{\mathrm{f}}(w)\left[\underline{\mathrm{x}}\left(w^{\prime \prime}\right)=\underline{\mathrm{x}}(\mathrm{w})\right]\right]\right]$

The individual concept approach to simple CQs with know is remimiscent of the account of rise, fall and change as $<\mathrm{s}, \mathrm{e}>$ taking verbs. For example, in (28a) (=6a), the NP the temperature of the lake contributes the individual concept in (27), which then combines with the intensional verb rise in (28b). This is completely parallel to the CQ example in (19)-(20).

(27) Semantic contribution of the NP the temperature of the lake:

$\lambda w^{\prime \prime} \cdot 1 x_{e}$ [temp-of-lake(x,w”)]

(28) a. The temperature of the lake is rising.

b. $\lambda w$. rise $\left(\lambda w^{\prime} \cdot x_{\mathrm{e}}\left[\right.\right.$ temp-of-lake $\left.\left.\left(\mathrm{x}, \mathrm{w}^{\prime}\right)\right], \mathrm{w}\right)$

If the individual concept approach is to succeed with know, it should also address the challenges posed by rise, fall and change. There is a long standing puzzle, attributed to Anil Gupta in Dowty, Wall and Peters (1981), for the individual concept approach to verbs like rise. The puzzle is the following. The syllogism in (29) is intuitively valid:

(29) Gupta’s syllogism:

i. Necessarily, the temperature is the price. ${ }^{6}$

ii. The temperature is rising.

iii. The price is rising.

However, its Montague-style translation (30) using individual concepts does not guarantee its validity:

(30) Dowty, Wall and Peters (with world variables explicit):

$$
\begin{aligned}
& \text { i. } \lambda \mathrm{w} . \forall \mathrm{w}^{\prime} \in \operatorname{Acc}(\mathrm{w})\left[\exists \mathrm { x } _ { < \mathrm { s } , \mathrm { e } } \left[\mathrm { H } \left[\mathrm{y}\left[\operatorname{temp}\left(\mathrm{y}, \mathrm{w}^{\prime}\right) \leftrightarrow \mathrm{x}=\mathrm{y}\right] \wedge\right.\right.\right. \\
& \left.\exists \mathrm{z}_{<\mathrm{s}, \mathrm{e}}\left[\mathrm{v}\left[\mathrm{v}\left[\operatorname{price}\left(\mathrm{v}, \mathrm{w}^{\prime}\right) \leftrightarrow \mathrm{z}=\mathrm{v}\right] \wedge \mathrm{x}\left(\mathrm{w}^{\prime}\right)=\mathrm{z}\left(\mathrm{w}^{\prime}\right)\right]\right]\right]
\end{aligned}
$$

\footnotetext{
${ }^{6}$ Following Nathan (2005:61), (29i) can be understood as the elliptical version of e.g. Necessarily, the temperature in degrees Fahrenheit is the price in cents of a can of Coke.
} 
ii. $\lambda \mathrm{w} . \exists \mathrm{x}_{<\mathrm{s}, \mathrm{e}>}[\forall \mathrm{y}[\operatorname{temp}(\mathrm{y}, \mathrm{w}) \leftrightarrow \mathrm{x}=\mathrm{y}] \wedge \operatorname{rise}(\mathrm{x}, \mathrm{w})]$
iii. $\lambda \mathrm{w} . \exists \mathrm{z}_{<\mathrm{s}, \mathrm{e}>}[\forall \mathrm{v}[\operatorname{price}(\mathrm{v}, \mathrm{w}) \leftrightarrow \mathrm{z}=\mathrm{v}] \wedge \operatorname{rise}(\mathrm{z}, \mathrm{w})]$

To show that (30) does not guarantee the validity of the syllogism, Dowty, Wall and Peters (1981) sketch the model in (31), where there are three indices temporally ordered $\left(\mathrm{i}_{1}<\mathrm{i}_{2}<\mathrm{i}_{3}\right)$ and all indices stand to each other in the accessibility relation encoded by necessarily. In this model, (30i) is true at index $\mathrm{i}_{1}$, since at all indices $\mathrm{i}$ accessible from $\mathrm{i}_{1}$ [[the temperature is the price]](i) is TRUE: the unique $\mathrm{x}_{<\mathrm{s}, \mathrm{e}>}$ in [[temperature] $\left(\mathrm{i}_{1}\right)$ and the unique $\mathrm{z}_{<\mathrm{s}, \mathrm{e}>}$ in [1price]]( $\left.\mathrm{i}_{1}\right)$ are such that $\mathrm{x}\left(\mathrm{i}_{1}\right)=\mathrm{z}\left(\mathrm{i}_{1}\right)$ (since they both equal 99); the unique $\mathrm{x}_{<\mathrm{s}, \mathrm{e}}$ in [[temperature $]]\left(\mathrm{i}_{2}\right)$ and the unique $\mathrm{z}_{<\mathrm{s}, \mathrm{e}>}$ in $[$ price $]\left(\mathrm{i}_{2}\right)$ are such that $\mathrm{x}\left(\mathrm{i}_{2}\right)=\mathrm{z}\left(\mathrm{i}_{2}\right)$ (since they both equal 90); and the unique $\mathrm{x}_{<\mathrm{s}, \mathrm{e}>}$ in [Itemperature]]( $\left.\mathrm{i}_{3}\right)$ and the unique $\mathrm{z}_{<\mathrm{s}, \mathrm{e}>}$ in $[[$ price $]]\left(\mathrm{i}_{3}\right)$ are such that $\mathrm{x}\left(\mathrm{i}_{3}\right)=\mathrm{z}\left(\mathrm{i}_{3}\right)$ (since they both equal 81 ). The formula (30ii) is also true in this model when evaluated at $i_{1}$, since the unique $\mathrm{X}_{<\mathrm{s}, \mathrm{e}}>$ in [[temperature $]\left(\mathrm{i}_{1}\right)$ is a rising function. But the conclusion (30iii) is false at $\mathrm{i}_{1}$, since the unique $\mathrm{z}_{<\mathrm{s}, \mathrm{e}}$ in [[price $]\left(\mathrm{i}_{1}\right)$ is not a rising but a falling function.

$$
\begin{aligned}
& \text { Model, with indices } \mathrm{i}_{1}<\mathrm{i}_{2}<\mathrm{i}_{3} \text { and all accessible from each other: } \\
& \text { [[temp. } \left.\left.\left.]\left(\mathrm{i}_{1}\right)=\left\{\mathrm{T}_{1}\right\} \quad \text { [temp. }\right]\left(\mathrm{i}_{2}\right)=\left\{\mathrm{T}_{2}\right\} \quad \text { [[temp. }\right]\right]\left(\mathrm{i}_{3}\right)=\left\{\mathrm{T}_{3}\right\} \\
& \text { with } \mathrm{T}_{1}\left(\mathrm{i}_{1}\right)=99 \quad \text { with } \quad \mathrm{T}_{2}\left(\mathrm{i}_{1}\right)=89 \text { with } \mathrm{T}_{3}\left(\mathrm{i}_{1}\right)=79 \\
& \mathrm{~T}_{1}\left(\mathrm{i}_{2}\right)=100 \quad \mathrm{~T}_{2}\left(\mathrm{i}_{2}\right)=90 \quad \mathrm{~T}_{3}\left(\mathrm{i}_{2}\right)=80 \\
& \begin{array}{lll}
\mathrm{T}_{1}\left(\mathrm{i}_{3}\right)=101 & \mathrm{~T}_{2}\left(\mathrm{i}_{3}\right)=91 & \mathrm{~T}_{3}\left(\mathrm{i}_{3}\right)=81
\end{array} \\
& \text { [[price } \left.\left.\left.\left.]]\left(\mathrm{i}_{1}\right)=\left\{\mathrm{P}_{1}\right\} \quad \text { [Lprice }\right]\right]\left(\mathrm{i}_{2}\right)=\left\{\mathrm{P}_{2}\right\} \quad \text { [[price }\right]\right]\left(\mathrm{i}_{3}\right)=\left\{\mathrm{P}_{3}\right\} \\
& \text { with } \quad \mathrm{P}_{1}\left(\mathrm{i}_{1}\right)=99 \quad \text { with } \quad \mathrm{P}_{2}\left(\mathrm{i}_{1}\right)=91 \text { with } \mathrm{P}_{3}\left(\mathrm{i}_{1}\right)=83 \\
& \mathrm{P}_{1}\left(\mathrm{i}_{2}\right)=98 \quad \mathrm{P}_{2}\left(\mathrm{i}_{2}\right)=90 \quad \mathrm{P}_{3}\left(\mathrm{i}_{2}\right)=82 \\
& \begin{array}{lll}
\mathrm{P}_{1}\left(\mathrm{i}_{3}\right)=97 & \mathrm{P}_{2}\left(\mathrm{i}_{3}\right)=89 & \mathrm{P}_{3}\left(\mathrm{i}_{3}\right)=81
\end{array}
\end{aligned}
$$

Hence, the formulas in (30) do not correctly translate the valid argument (29). ${ }^{7}$ The question is, what should be changed in the formal translations to secure the validity of the argument.

Lasersohn (2005) argues that the Montague-style translations in (30) are problematic because they presume that the English nouns temperature and price express properties of individual concepts rather than simple properties of individuals, thus allowing for models like (31). Under the Russellian treatment of definite descriptions, one is forced to assume the former: e.g. in (30ii), we have the formula rise $\left(x_{<s e>}, w\right)$ and, since $x$ is queated to $y$, we must have the formula

\footnotetext{
${ }^{7}$ Gupta's syllogism for individual concepts with rise can be reproduced for CQs with know. Consider reading A of (i.ii) and (i.iii) below. Under reading A, (i.ii) says that the unique price $\mathrm{x}_{<\mathrm{s}, \mathrm{e}}>$ first announced on the radio is such that Martin knows $\mathrm{x}_{<\mathrm{s}, \mathrm{e}}$ (regardless of whether he knows when and where it was announced). Similarly, reading $\mathrm{A}$ of (i.iii) says that the unique price $\mathrm{z}_{<\mathrm{s}, \mathrm{e}}>$ first announced on TV is such that Martin knows $\mathrm{z}_{<s, \mathrm{e}}$. Under these readings, the argument in (i) is valid. Then, translating the syllogism in a way parallel to (30) leads to the same puzzle as before.

(i) i. Necessarily, the price announced first on the radio is the price announced first on TV. ii. Martin knows the price first announced on the radio. iii. Martin knows the price first announced on TV.
} 
temp $\left(y_{<s e}>w\right)$ as well. This means the English noun temperature corresponds to the $\lambda$-expression $\lambda w \lambda y_{<s e>}>$ temp $\left(y_{<s e>}>w\right)$, that is, it expresses a property of individual concepts. (The same reasoning holds for the noun price.) Lasersohn notes that, if one assumes instead a Fregean approach to definite descriptions, the syllogism (29) can be translated using the simpler formulas $\operatorname{temp}\left(x_{e}, w\right)$ and price $\left(v_{e}, w\right)$, thus assuming the simpler meanings as properties of individuals. Using the Fregean approach to definite descriptions, Lasersohn proposes to translate (29) as in (32). The formulas in (32) form a valid argument.

(32) Lasersohn's (2005) translation of Gupta's syllogism (with world variables explicit):

i. $\lambda \mathrm{w} . \forall \mathrm{w}^{\prime} \in \operatorname{Acc}(\mathrm{w})\left[\mathrm{tx}_{\mathrm{e}}\left[\operatorname{temp}\left(\mathrm{x}, \mathrm{w}^{\prime}\right)\right]=\mathrm{zz}_{\mathrm{e}}\left[\operatorname{price}\left(\mathrm{x}, \mathrm{w}^{\prime}\right)\right]\right]$

ii. $\lambda w$. rise $\left(\lambda w^{\prime} . x_{\mathrm{e}}\left[\operatorname{temp}\left(\mathrm{x}, \mathrm{w}^{\prime}\right)\right], \mathrm{w}\right)$

iii. $\lambda w$. rise $\left(\lambda w^{\prime} \cdot 1 z_{e}\left[\right.\right.$ price $\left.\left.\left(z, w^{\prime}\right)\right], w\right)$

Although the Fregean treatment of definite descriptions solves the puzzle for the particular syllogism in (29), this solution is not general enough. The puzzle re-arises in parallel syllogisms where this solution cannot be applied. To see this, consider the variant of Gupta's syllogism in (33), also valid:

(33) i. Necessarily, every price that John knows is a/one price that Fred knows ii. One of the prices that John knows is rising.

iii. One of the prices that Fred knows is rising.

Here the NPs at issue are not definite descriptions, and the N-bars price that John knows and price that Fred knows need to express precisely $<\mathrm{s},<<\mathrm{s}, \mathrm{e}>$, t $>>$ functions, i.e. properties of individual concepts. This means that Lasersohn's solution cannot be used here. The quantified NPs will translate as quantification over the variables $x$ and $z$ of type $<\mathrm{s}, \mathrm{e}>$ in (34), which will serve as arguments both in the formula rise $(x, w)$ and in the formula price-NP-knows $(x, w)$. This means that the corresponding English nouns (or N') express properties of individual concepts and that models like (35) falsifying the syllogism are possible.

i. $\quad \lambda \mathrm{w} . \forall \mathrm{w}^{\prime} \in \operatorname{Acc}(\mathrm{w})\left[\forall \mathrm{x}_{<\mathrm{s}, \mathrm{e}}\left[\right.\right.$ price-J-knows $\left(\mathrm{x}, \mathrm{w}^{\prime}\right) \rightarrow$

$$
\left.\left.\exists \mathrm{z}<\mathrm{s,e},\left[\text { price-F-knows }\left(\mathrm{z}, \mathrm{w}^{\prime}\right) \wedge \mathrm{x}\left(\mathrm{w}^{\prime}\right)=\mathrm{z}\left(\mathrm{w}^{\prime}\right)\right]\right]\right]
$$

ii. $\lambda \mathrm{w} . \exists \mathrm{x}_{<\mathrm{s}, \mathrm{e}}[\mathrm{price}-\mathrm{J}-\mathrm{knows}(\mathrm{x}, \mathrm{w}) \wedge \operatorname{rise}(\mathrm{x}, \mathrm{w})]$

iii. $\lambda \mathrm{w} . \exists \mathrm{z}_{<\mathrm{s}, \mathrm{e}}[\mathrm{p}$ price-F-knows $(\mathrm{z}, \mathrm{w}) \wedge \operatorname{rise}(\mathrm{z}, \mathrm{w})]$

(35) Model, with indices $\mathrm{i}_{1}<\mathrm{i}_{2}<\mathrm{i}_{3}$ and all accessible from each other:

$$
\begin{aligned}
& \text { 【price } J \text { knows } \rrbracket\left(\mathrm{i}_{1}\right) \text { 【price } J \text { knows } \rrbracket\left(\mathrm{i}_{2}\right) \quad \text { 【price } J \text { knows } \rrbracket\left(\mathrm{i}_{3}\right) \\
& =\left\{\mathrm{J}_{1}\right\} \quad=\left\{\mathrm{J}_{2}\right\} \quad=\left\{\mathrm{J}_{3}\right\} \\
& \text { with } \mathrm{J}_{1}\left(\mathrm{i}_{1}\right)=99 \pitchfork \text { with } \mathrm{J}_{2}\left(\mathrm{i}_{1}\right)=89 \pitchfork \text { with } \mathrm{J}_{3}\left(\mathrm{i}_{1}\right)=79 \pitchfork \\
& \mathrm{J}_{1}\left(\mathrm{i}_{2}\right)=\$ 1.00 \quad \mathrm{~J}_{2}\left(\mathrm{i}_{2}\right)=90 \pitchfork \quad \mathrm{J}_{3}\left(\mathrm{i}_{2}\right)=80 \pitchfork \\
& \mathrm{J}_{1}\left(\mathrm{i}_{3}\right)=\$ 1.01 \quad \mathrm{~J}_{2}\left(\mathrm{i}_{3}\right)=91 \$ \quad \mathrm{~J}_{3}\left(\mathrm{i}_{3}\right)=81 \mathrm{\phi}
\end{aligned}
$$

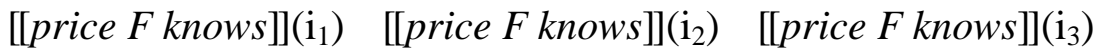




$$
\begin{array}{llllll}
=\left\{\mathrm{F}_{1}\right\} & \multicolumn{3}{c}{=\left\{\mathrm{F}_{2}\right\}} & & =\left\{\mathrm{F}_{3}\right\} \\
\text { with } & \mathrm{F}_{1}\left(\mathrm{i}_{1}\right)=99 \pitchfork & \text { with } & \mathrm{F}_{2}\left(\mathrm{i}_{1}\right)=91 \pitchfork & \text { with } & \mathrm{F}_{3}\left(\mathrm{i}_{1}\right)=83 \pitchfork \\
& \mathrm{F}_{1}\left(\mathrm{i}_{2}\right)=98 \pitchfork \\
& & \mathrm{F}_{2}\left(\mathrm{i}_{2}\right)=90 \pitchfork & & \mathrm{F}_{3}\left(\mathrm{i}_{2}\right)=82 \pitchfork \\
& \mathrm{F}_{1}\left(\mathrm{i}_{3}\right)=97 \pitchfork & & \mathrm{F}_{2}\left(\mathrm{i}_{3}\right)=89 \pitchfork & & \mathrm{F}_{3}\left(\mathrm{i}_{3}\right)=81 \pitchfork
\end{array}
$$

What changes could be made to the Montague-style translations in (34) to make them form a valid argument? Note that, besides the differences in the translation of definite descriptions and in the functions expressed by the nouns, the Montague-style translation (30i) and Lasersohn's translation (32i) differed in another respect. In the first case, we extract the unique $\mathrm{X}_{<\mathrm{s} \text {, } \mathrm{e}}>\mathrm{z}_{<\mathrm{s} \text {,e }}$ from the NP's extension at $w^{\prime}$, and we apply it to the world $w^{\prime}$ before obtaining the equation $x\left(w^{\prime}\right)=z\left(w^{\prime}\right)$. This is sketched in (36). This leads to the original Montague-style translation (30i), repeated below as (37).

$$
\begin{aligned}
& \lambda \mathrm{w} . \forall \mathrm{w}^{\prime} \in \operatorname{Acc}(\mathrm{w}) \\
& \text { [ [the unique } \left.\left.\mathrm{x}_{<\mathrm{s}, \mathrm{e}>} \text { such that }\left\{\mathrm{x}_{<\mathrm{s}, \mathrm{e}>}\right\} \in[\text { the temperature }]\right]^{\text {extension-at-w'] }} \text { ( }^{\prime}{ }^{\prime}\right) \\
& \left.=\left[\text { the unique } \mathrm{z}_{<\mathrm{s}, \mathrm{e}}>\text { such that }\left\{\mathrm{z}_{<\mathrm{s}, \mathrm{e}>}\right\} \in[[\text { the price }]]^{\text {extension-at-w'}}\right]\left(\mathrm{w}^{\prime}\right)\right] \\
& \lambda \mathrm{w} . \forall \mathrm{w}^{\prime} \in \operatorname{Acc}(\mathrm{w})\left[\exists \mathrm { x } _ { < \mathrm { s } , \mathrm { e } > } \left[\forall \mathrm{y}\left[\operatorname{temp}\left(\mathrm{y}, \mathrm{w}^{\prime}\right) \leftrightarrow \mathrm{x}=\mathrm{y}\right] \wedge\right.\right. \\
& \left.\left.\exists \mathrm{z}_{<\mathrm{s}, \mathrm{e}>}\left[\forall \mathrm{v}\left[\text { price }\left(\mathrm{v}, \mathrm{w}^{\prime}\right) \leftrightarrow \mathrm{z}=\mathrm{v}\right] \wedge \mathrm{x}\left(\mathrm{w}^{\prime}\right)=\mathrm{z}\left(\mathrm{w}^{\prime}\right)\right]\right]\right]
\end{aligned}
$$

In Lasersohn's case, we take the unique individual $\mathrm{rx}_{\mathrm{e}}\left[\operatorname{temp}\left(\mathrm{x}, \mathrm{w}^{\prime}\right)\right]$ / $z_{e}\left[\right.$ price $\left.\left(z, w^{\prime}\right)\right]$ that equals the NP's extension at $w^{\prime}$, and we form directly the equation $\mathrm{rx}_{\mathrm{e}}\left[\operatorname{temp}\left(\mathrm{x}, \mathrm{w}^{\prime}\right)\right]=\mathrm{z}_{\mathrm{e}}\left[\right.$ price $\left.\left(\mathrm{x}, \mathrm{w}^{\prime}\right)\right]{ }^{8}{ }^{8}$ This is sketched in (38). The result is Lasersohn's translation (32i), repeated here as (39).

$$
\begin{aligned}
& \lambda \mathrm{w} . \forall \mathrm{w}^{\prime} \in \operatorname{Acc}(\mathrm{w}) \\
& \left.\quad\left[\text { the unique } \mathrm{x}_{\mathrm{e}} \text { that equals [[the temperature }\right]\right]^{\text {extension-at-w' }}= \\
& \text { the unique } \left.\left.\left.\mathrm{z}_{\mathrm{e}} \text { that equals [[the price }\right]\right]^{\text {extension-at-w' }}\right]
\end{aligned}
$$

$$
\lambda \mathrm{w} . \forall \mathrm{w}^{\prime} \in \operatorname{Acc}(\mathrm{w})\left[\mathrm{lx}_{\mathrm{e}}\left[\operatorname{temp}\left(\mathrm{x}, \mathrm{w}^{\prime}\right)\right]=\mathrm{tz}_{\mathrm{e}}\left[\operatorname{price}\left(\mathrm{x}, \mathrm{w}^{\prime}\right)\right]\right]
$$

To solve the variant of Gupta's syllogism in (33), I propose to follow the latter strategy: We quantify over an $\mathrm{x}_{<\mathrm{s}, \mathrm{e}}>/ \mathrm{z}_{<\mathrm{s}, \mathrm{e}}>$ extracted from the NP's extension, and we produce the equation $\mathrm{x}=\mathrm{z}$ directly, without applying $\mathrm{x}_{<\mathrm{s}, \mathrm{e}>} /$ $\mathrm{z}_{<\mathrm{s}, \mathrm{e}>}$ to any world $\mathrm{w}^{\prime}$. This means that, in (33i), crosscategorial be equates two individual concepts $\mathrm{x}_{<\mathrm{s}, \mathrm{e}}>$ and $\mathrm{z}_{<\mathrm{s}, \mathrm{e}}$, not two individuals $\mathrm{X}_{<\mathrm{s}, \mathrm{e}}>\left(\mathrm{W}^{\prime}\right)$ and $\mathrm{Z}_{<\mathrm{s}, \mathrm{e}}>\left(\mathrm{W}^{\prime}\right)$. The proposed translations for the variant of Gupta's syllogism are in (40). When evaluated at a world $\mathrm{w}_{1}$ that is accessible to itself, (40) forms a valid argument, as the reader can check for herself.

\footnotetext{
${ }^{8}$ Alternatively to (38), we can take the unique $\lambda w^{\prime} . \mathrm{xx}_{\mathrm{e}}\left[\operatorname{temp}\left(\mathrm{x}, \mathrm{w}^{\prime}\right)\right] / \lambda \mathrm{w}^{\prime} .1 \mathrm{z}_{\mathrm{e}}\left[\mathrm{price}\left(\mathrm{z}, \mathrm{w}^{\prime}\right)\right]$ that is the NP's intension, and apply it to $w^{\prime}$ before obtaining the equation ${ }^{\prime} x_{e}\left[t e m p\left(x, w^{\prime}\right)\right]=$ $\mathrm{zz}_{\mathrm{e}}\left[\mathrm{price}\left(\mathrm{x}, \mathrm{w}{ }^{\prime}\right)\right]$. The result is the same.
} 


$$
\begin{aligned}
& \text { i. } \lambda \mathrm{w} \cdot \forall \mathrm{w}^{\prime} \in \operatorname{Acc}(\mathrm{w})\left[\forall \mathrm{x}_{<\mathrm{s}, \mathrm{e}}[\text { price-J-knows(x,w') } \rightarrow\right. \\
& \left.\left.\exists \mathrm{z}_{<\mathrm{s}, \mathrm{e}}\left[\text { price-F-knows }\left(\mathrm{z}, \mathrm{w}^{\prime}\right) \wedge \mathrm{x}=\mathrm{z}\right]\right]\right] \\
& \text { ii. } \lambda \mathrm{w} . \exists \mathrm{x}_{<\mathrm{s}, \mathrm{e}}[\mathrm{price}-\mathrm{J}-\operatorname{knows}(\mathrm{x}, \mathrm{w}) \wedge \operatorname{rise}(\mathrm{x}, \mathrm{w})] \\
& \text { iii. } \lambda \mathrm{w} \text {. } \exists \mathrm{z}_{<\mathrm{s}, \mathrm{e}}[\mathrm{price}-\mathrm{F}-\mathrm{knows}(\mathrm{z}, \mathrm{w}) \wedge \operatorname{rise}(\mathrm{z}, \mathrm{w})]
\end{aligned}
$$

\section{Propositional Account}

As we have seen, the individual concept account assumes a parallel treatment of individual concepts (ICs) with rise / fall / change and CQs with know. However, there are empirical differences suggesting that, at some point, the two types of NPs need to be distinguished. The question is how and from what point on in the derivation the two types differ.

The first difference concerns coordination. Nathan (2005:55) notes that two verbs like rise and fall can be coordinated and share their NP argument in (41a). Similarly, two CQ-taking verbs can be coordinated and share the CQ argument, as in (41b). However, coordination between rise/fall and know sharing the NP argument leads to ungrammaticality, witness (41c). ${ }^{9}$ This pattern suggest that the IC argument of rise is, as a whole, different from the CQ argument of know.

a. [The price of milk $]_{\mathrm{IC}}$ fell last week and is rising this week.

b. [The price of milk] $]_{\mathrm{CQ}}$ is known to John and has been forgotten by Fred

c. *[The price of milk] ? fell last week and is known to John.

Building on Romero (2005a), Romero (2005b) develops a propositional account of CQ. Her aim is to account for the differences -including coordination structures and non-maximal readings- between NP arguments of extensional and intensional verbs (e.g. look for) on the one hand and CQs on the other. As it turns out, Romero's (2005b) propositional analysis of CQs can be also used to characterize the external difference between ICs with rise / fall / change and CQs with know. Internally, the compositional derivation of IC NPs and CQ NPs is the same. For example, when composing the pieces of the NP the price of milk, in both cases we obtain the individual concept in (42). In the case of rise / fall / change, the meaning of the verb combines directly with this individual concept, as shown in (43). In the case of know, the individual concept combines first with the answer operator ANS in (44a). The result is the propositional concept -type $<\mathrm{s},<\mathrm{s}, \mathrm{t}>>>_{-}$in (44b). It is this propositional concept, and not the original individual concept, that constitutes the semantic argument of know, as shown in $(44 c, d)$.

\footnotetext{
${ }^{9}$ See Romero (2004) for related observations about coordination of extensional verbs, regular intensional verbs like look for and CQ-taking verbs.
} 


$$
\begin{aligned}
& \text { [[the price of milk }]=\lambda \mathrm{w}^{*} .1 \mathrm{x}_{\mathrm{e}}\left[\text { price }\left(\mathrm{x}, \mathrm{milk}, \mathrm{w}^{*}\right)\right]
\end{aligned}
$$



a. ANS $_{\mathrm{STR}}=\lambda \mathrm{y}_{<\mathrm{s}, \mathrm{e}>} \lambda \mathrm{w} \lambda \mathrm{w}^{\prime} \cdot \mathrm{y}\left(\mathrm{w}^{\prime}\right)=\mathrm{y}(\mathrm{w})$

b. [[ $\left.\left.\left[\text { ANS }_{\text {STR }} \text { The price of milk }\right]_{C Q}\right]\right]$ $=\lambda w \lambda w^{\prime} .\left[\lambda w^{*} \cdot x_{e}\left[\right.\right.$ price $\left.\left(x, m i l k, w^{*}\right)\right]\left(w^{\prime}\right)=$ $\lambda \mathrm{w}^{*} .1 \mathrm{x}$ e[price $\left.\left.\left(\mathrm{x}, \mathrm{milk}, \mathrm{w}^{*}\right)\right](\mathrm{w})\right]$ $=\lambda \mathrm{w} \lambda \mathrm{w}^{\prime} \cdot\left[\mathrm{ix}\right.$ e $\left[\right.$ price $\left.\left.\left(\mathrm{x}, \operatorname{milk}, \mathrm{w}^{\prime}\right)\right]=\mathrm{xx}_{\mathrm{e}}[\operatorname{price}(\mathrm{x}, \mathrm{milk}, \mathrm{w})]\right]$

c. $[[k n o w]]=\lambda \mathrm{p}_{<\mathrm{s},<\mathrm{s}, \mathrm{t}>>} \lambda \mathrm{x}_{\mathrm{e}} \lambda \mathrm{w} . \forall \mathrm{w}^{\prime} \in \operatorname{Dox}_{\mathrm{x}}(\mathrm{w})\left[\mathrm{p}(\mathrm{w})\left(\mathrm{w}^{\prime}\right)=1\right]$

d. [[ [ANS STR The price of milk $]_{C Q}$ is known to John]] $=\lambda \mathrm{w} . \forall \mathrm{w}^{\prime} \in \operatorname{Dox}_{\mathrm{x}}(\mathrm{w})\left[\mathrm{wx}_{\mathrm{e}}\left[\operatorname{price}\left(\mathrm{x}, \mathrm{milk}_{\mathrm{w}} \mathrm{w}^{\prime}\right)\right]=\mathrm{vx}_{\mathrm{e}}[\operatorname{price}(\mathrm{x}, \mathrm{milk}, \mathrm{w})]\right]$

The second difference between ICs with rise / fall / change and CQs with know concerns the internal structure of the NP, more concretely, the nature of the head noun (Löbner 1981, Janssen 1984, Nathan 2005). Relational nouns (price, temperature, governor, etc.) and non-relational nouns (picture on Jordan's wall, semanticist, etc.) form acceptable ICs with rise / fall / change. The situation is different for CQs. Relational nouns form in general acceptable CQs (though there are numerous exceptions), whereas non-relational nouns are unacceptable CQs. The contrast between ICs with rise / fall / change and CQs with respect to nonrelational verbs is illustrated by Nathan's (2005) examples (45) (=8) and (46).

(45) A: John says he visits his niece Jordan with some frequency, but when I asked him what picture she has on her wall, he had no idea.

B: The picture on Jordan's wall changes every month. \#That's why John didn't know the_picture on Jordan's wall.

(46) A: What's new at the linguistics department at USNDH?

B: The semanticist changed.

A: \# Really? Tell me the semanticist (now).

Nathan's (2005) solution to this internal difference between ICs with rise / fall / change and CQs is the following. Nathan assumes that NPs with rise / fall / change are individual concepts whereas CQs are propositional in nature, roughly as above. However, he proposes that this difference is not determined externally, but internally at the level of the head noun. This is achieved by assuming lexical entries of basic type $<\mathrm{s}$, $<\mathrm{e}$, $<\mathrm{et}>>>$ for relational nouns and of basic type $<$, et $>$ for non-relational nouns, and constraining shifting operations as in (47)-(48). The basic intensions of relational and non-relational nouns can be shifted to sets of 
individual concepts using the shifters in (47). Thus, both types of nouns will be able to head NP arguments of rise / fall / change:

Shifting from basic intensions to sets of ICs:
a. $<$ s, $<$ e,et $>>\rightarrow<$ se,t $>$ :
$\lambda \mathrm{P}_{<\mathrm{s},<\mathrm{e}, \mathrm{et}>>} \lambda \mathrm{x}_{<\mathrm{se}>} . \exists \mathrm{y}_{\mathrm{e}} \forall \mathrm{w}[\mathrm{P}(\mathrm{w})(\mathrm{y})(\mathrm{x}(\mathrm{w}))=1]$
b. $<$ s,et $>$
$\rightarrow<$ se,t $>$
$\lambda \mathrm{P}_{<\mathrm{s}, \mathrm{et}}>\lambda \mathrm{x}_{<\mathrm{se}}>\cdot \exists \mathrm{y}_{\mathrm{e}} \forall \mathrm{w}[\mathrm{P}(\mathrm{w})(\mathrm{x}(\mathrm{w}))=1 \wedge$ $\mathrm{R}(\mathrm{w})(\mathrm{y})(\mathrm{x}(\mathrm{w}))=1]$
where for any $\mathrm{N}_{<\mathrm{s} \text {,et }>}$ being shifted:$$
\forall \mathrm{w}_{1}, \mathrm{w}_{2} \forall \mathrm{x}_{\mathrm{e}}\left[\mathrm{N}\left(\mathrm{w}_{1}\right)(\mathrm{x}) \wedge \mathrm{N}\left(\mathrm{w}_{2}\right)(\mathrm{x}) \rightarrow\right.
$$$$
\left.\exists \mathrm{y}_{e}\left[\mathrm{R}\left(\mathrm{w}_{1}\right)(\mathrm{y})(\mathrm{x}) \wedge \mathrm{R}\left(\mathrm{w}_{2}\right)(\mathrm{y})(\mathrm{x})\right]\right]
$$

In contrast, the basic intensions of relational nouns, but not the basic intensions of non-relational nouns, can be shifted into sets of propositions. The shifter in (48a) performs the former shift, but no shifter is available to transform the <s,et $>$ function of a non-relational noun into a set of propositions. As [[know]] is assumed to combine with a set of propositions, a relational head noun will, but a non-relational head noun will not, constitute an NP complement of the adequate semantic type.

Shifting from basic intensions to sets of propositions:

a. $<\mathrm{s},<\mathrm{e}, \mathrm{et}>>\rightarrow<(\mathrm{e}),<\mathrm{st}, \mathrm{t}>>: \lambda \mathrm{P}_{<\mathrm{s},<\mathrm{e}, \mathrm{et}>>} \lambda \mathrm{y}_{\mathrm{e}} \lambda \mathrm{p}_{<\mathrm{st}\rangle} . \exists \mathrm{x}_{\mathrm{e}}\left[\mathrm{p}=\lambda \mathrm{w}_{1} . \mathrm{P}\left(\mathrm{w}_{1}\right)(\mathrm{y})(\mathrm{x})\right]$

b. $<$ s,et $><$ st, t $>$

I do not presently have an alternative account of this intriguing difference between ICs with rise / fall / change and CQs with respect to their head noun. Nevertheless, I would like to point out that making the propositional nature of CQs stem from the internal semantics of the NP -as in Nathan's propositional account- instead of deriving it externally to the NP -as in Romero (2005b)- faces some challenges.

The first challenge concerns the aforementioned ambiguity between reading $\mathrm{A}$ and reading $\mathrm{B}$. This ambiguity arises not only with CQs with know, as we saw in (3), but also with ICs with change, as in (49):

(49) The price that had to change changed.

a. Reading A: "There is a price $\mathrm{x}_{<\mathrm{s}, \mathrm{e}>}-\mathrm{e}$.g. the price of milk- that had to change and that has changed."

b. Reading B: “There used to be a price $\mathrm{x}_{<\mathrm{s}, \mathrm{e}>}-\mathrm{e}$.g. the price of milk- that had to change, but now the price that has to change is another one -e.g. the price of ham."

In Romero's (2005b) propositional account, the ambiguity between reading $\mathrm{A}$ and reading $\mathrm{B}$ stems from the choice between the extension and the intension of the original NP, regardless of whether the main verb is rise / fall / 
change or know. If the semantic contribution of the NP directly combines with the verbs rise / fall / change, then we have exactly the analysis that we saw in section 3 , applied now to (49) in (50)-(51). If the semantic contribution of the NP combines first with the ANS operator and later with the verb know, we have the derivations in (52)-(53):

(50) Reading A of The price that had to change changed:

a. Extension of the NP in w:

$\underline{\underline{x}}<\mathrm{s}, \mathrm{e}>\left[\right.$ price $(\underline{\mathrm{x}}, \mathrm{w}) \& \forall \mathrm{w}^{\prime \prime} \in \operatorname{Deo}(\mathrm{w})$ [change( $(\underline{\mathrm{x}}, \mathrm{w}$ ")] ]

b. Change + extension of the NP:

$\lambda w$. change ( $\underline{x}<<s, \mathrm{e}>\left[\operatorname{price}(\underline{x}, w) \& \forall w^{\prime \prime} \in \operatorname{Deo}(w)\right.$ [change $\left.\left.\left.\left(\underline{x}, w^{\prime \prime}\right)\right]\right], w\right)$

(51) Reading B of The price that had to change changed:

a. Intension of the NP:

$\lambda \mathrm{w}^{*} . \underline{\underline{\mathrm{x}}}<\mathrm{s,e>}$ [ price $\left(\underline{\mathrm{x}}, \mathrm{w}^{*}\right) \& \forall \mathrm{w}^{\prime \prime} \in \operatorname{Deo}\left(\mathrm{w}^{*}\right)$ [change $\left.\left.\left(\underline{\mathrm{x}}, \mathrm{w}^{\prime \prime}\right)\right]\right]$

b. Change + intension of the NP:

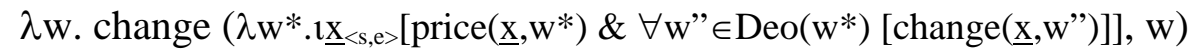

(52) Reading A of John knows the price that Fred knows under Romero's (2005b) propositional account:

a. Extension of the NP in w:

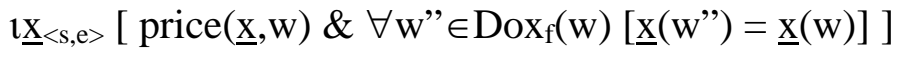

b. ANS + extension of the NP:

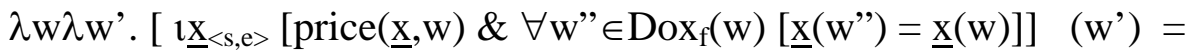
$\underline{\underline{\mathrm{X}}}\left\langle\mathrm{s}, \mathrm{e}>\left[\operatorname{price}(\underline{\mathrm{x}}, \mathrm{w}) \& \forall \mathrm{w}^{\prime \prime} \in \operatorname{Dox}_{\mathrm{f}}(\mathrm{w})\left[\underline{\mathrm{x}}\left(\mathrm{w}^{\prime \prime}\right)=\underline{\mathrm{x}}(\mathrm{w})\right]\right] \quad(\mathrm{w}) \quad\right]$

c. Know + ANS(extension of the NP):

$\lambda \mathrm{w} . \forall \mathrm{w}^{\prime} \in \operatorname{Dox}_{\mathrm{j}}(\mathrm{w})$

$\left[\underline{\underline{\mathrm{X}}}<\mathrm{s}, \mathrm{e}>\left[\operatorname{price}(\underline{\mathrm{x}}, \mathrm{w}) \& \forall \mathrm{w}^{\prime \prime} \in \operatorname{Dox}_{\mathrm{f}}(\mathrm{w})\left[\underline{\mathrm{x}}\left(\mathrm{w}^{\prime \prime}\right)=\underline{\mathrm{x}}(\mathrm{w})\right]\right] \quad\left(\mathrm{w}^{\prime}\right)=\right.$ $\underline{\underline{\mathrm{X}}}<\mathrm{s, \textrm {e } >}$ [price $\left.\left.(\underline{\mathrm{x}}, \mathrm{w}) \& \forall \mathrm{w}^{\prime \prime} \in \operatorname{Dox}_{\mathrm{f}}(\mathrm{w})\left[\underline{\mathrm{x}}\left(\mathrm{w}^{\prime \prime}\right)=\underline{\mathrm{x}}(\mathrm{w})\right]\right] \quad(\mathrm{w})\right]$

(53) Reading B f John knows the price that Fred knows under Romero's (2005b) propositional account:

a. Intension of the NP:

$\lambda \mathrm{w}^{*} . \underline{\mathrm{x}}<\mathrm{s}, \mathrm{e}>\left[\operatorname{price}\left(\underline{\mathrm{x}}, \mathrm{w}^{*}\right) \& \forall \mathrm{w}^{\prime \prime} \in \operatorname{Dox}_{\mathrm{f}}\left(\mathrm{w}^{*}\right)\left[\underline{\mathrm{x}}\left(\mathrm{w}^{\prime \prime}\right)=\underline{\mathrm{x}}\left(\mathrm{w}^{*}\right)\right]\right]$

b. ANS + intension of the NP:

$\lambda \mathrm{w} \lambda \mathrm{w}^{\prime}$. $\left[\lambda \mathrm{w}^{*} . \underline{\mathrm{x}_{\mathrm{x}, \mathrm{e}, \mathrm{e}}}\left[\operatorname{price}\left(\underline{\mathrm{x}}, \mathrm{w}^{*}\right) \& \forall \mathrm{w}^{\prime \prime} \in \operatorname{Dox}_{\mathrm{f}}\left(\mathrm{w}^{*}\right)\left[\underline{\mathrm{x}}\left(\mathrm{w}^{\prime \prime}\right)=\underline{\mathrm{x}}\left(\mathrm{w}^{*}\right)\right]\right]\left(\mathrm{w}^{\prime}\right)\right.$

$\left.=\lambda \mathrm{w}^{*} . \underline{\underline{\mathrm{x}}<\mathrm{s}, \mathrm{e}}\left[\mathrm{price}\left(\underline{\mathrm{x}}, \mathrm{w}^{*}\right) \& \forall \mathrm{w}^{\prime \prime} \in \operatorname{Dox}_{\mathrm{f}}\left(\mathrm{w}^{*}\right)\left[\underline{\mathrm{x}}\left(\mathrm{w}^{\prime \prime}\right)=\underline{\mathrm{x}}\left(\mathrm{w}^{*}\right)\right]\right](\mathrm{w})\right]$

c. ANS + intension of the NP, simplified:

$\lambda w_{\lambda} w^{\prime}$. [ $\underline{1} \underline{\mathrm{x}}_{<\mathrm{s}, \mathrm{e}}>\left[\operatorname{price}\left(\underline{\mathrm{x}}, \mathrm{w}^{\prime}\right) \& \forall \mathrm{w}^{\prime \prime} \in \operatorname{Dox}_{\mathrm{f}}\left(\mathrm{w}^{\prime}\right)\left[\underline{\mathrm{x}}\left(\mathrm{w}^{\prime \prime}\right)=\underline{\mathrm{x}}\left(\mathrm{w}^{\prime}\right)\right]\right]=$ $\left.\underline{\underline{x}}<s, e>\left[\operatorname{price}(\underline{x}, w) \& \forall w^{\prime \prime} \in \operatorname{Dox}_{\mathrm{f}}(\mathrm{w})\left[\underline{x}\left(w^{\prime \prime}\right)=\underline{x}(w)\right]\right]\right]$

d. Know + ANS(intension of the NP):

$\lambda \mathrm{w} . \forall \mathrm{w}^{\prime} \in \operatorname{Dox}_{\mathrm{j}}(\mathrm{w})$

$\left[\underline{\underline{\mathrm{x}}}<\mathrm{s}, \mathrm{e}>\left[\operatorname{price}\left(\underline{\mathrm{x}}, \mathrm{w}^{\prime}\right) \& \forall \mathrm{w}^{\prime \prime} \in \operatorname{Dox}_{\mathrm{f}}\left(\mathrm{w}^{\prime}\right)\left[\underline{\mathrm{x}}\left(\mathrm{w}^{\prime \prime}\right)=\underline{\mathrm{x}}\left(\mathrm{w}^{\prime}\right)\right]\right]=\right.$ 


$$
\underline{\mathrm{x}_{<\mathrm{s}, \mathrm{e}}>}\left[\operatorname{price}(\underline{\mathrm{x}}, \mathrm{w}) \& \forall \mathrm{w}, \in \operatorname{Dox}_{\mathrm{f}}(\mathrm{w})[\underline{\mathrm{x}}(\mathrm{w})=\underline{\mathrm{x}}(\mathrm{w})]\right]
$$

In Nathan's (2005) propositional account, the ambiguity between reading $\mathrm{A}$ and $\mathrm{B}$ is not given a unified analysis but must be derived using different means in each case. For ambiguous ICs with rise / fall / change, the strategy in (50)-(51) is adopted. But, for ambiguous CQs with know, we cannot apply the same strategy because we already have (a set of) propositions at the level of the head noun. Instead, the special shifter in (54) is needed to generate the truth conditions (55): $:^{10}$

(54) Special shifter $<$ s, $<$ e, et $>>\rightarrow<$ st, $>>$ for reading B with CQs:

For any Relative Clause intension $\mathrm{Q}_{<\mathrm{s},<\mathrm{st}, \mathrm{t}>>}$ :

$$
\lambda \mathrm{P}_{<\mathrm{s},<\mathrm{e}, \mathrm{et}>>} \lambda \mathrm{p}_{<\mathrm{st}>} . \exists \mathrm{y}_{\mathrm{e}}\left[\mathrm{p}=\lambda \mathrm{w}^{\prime} . \exists \mathrm{x}_{\mathrm{e}}\left[\mathrm{Q}\left(\mathrm{w}^{\prime}\right)\left(\lambda \mathrm{w}^{\prime} . \mathrm{P}\left(\mathrm{w}^{\prime \prime}\right)(\mathrm{y})(\mathrm{x})\right)=1\right]\right]
$$

(55) Reading B of John knows the price that Fred knows:

$\lambda \mathrm{w}_{0} . \forall \mathrm{w} \in \operatorname{Dox}_{\mathrm{j}}\left(\mathrm{w}_{0}\right)$

$\left[\mathrm{pp}\left[\mathrm{C}(\mathrm{p}) \wedge \exists \mathrm{y}_{\mathrm{e}}\left[\mathrm{p}=\lambda \mathrm{w}^{\prime} . \exists \mathrm{x}_{\mathrm{e}} \forall \mathrm{w}^{\prime \prime} \in \operatorname{Dox}_{\mathrm{f}}\left(\mathrm{w}^{\prime}\right)\left[\mathrm{y} \operatorname{costs} \mathrm{x}\right.\right.\right.\right.$ at $\left.\left.\left.\left.\mathrm{w}^{\prime \prime}\right]\right]\right](\mathrm{w})=1\right]$

"John knows the unique true proposition $\mathrm{p}$ in the set $\{$ 'There is some $\mathrm{x}$ such that Fred knows that the milk costs $\mathrm{x}$ ', 'There is some $\mathrm{x}$ such that Fred knows that the ham costs $x$ ', 'There is some $x$ such that Fred knows that the oil costs $\left.x^{\prime}, \ldots\right\}$.”

A second challenge for an account deriving the propositional nature of CQs internally to the NP arises with nesting of know and rise / fall / change. Consider example (56), in which a CQ with know is nested within ICs with rise:

(56) The price / One of the prices that John knows is rising.

In Nathan's account, since the verb in the Relative Clause is know and the argument of know is intrinsically of propositional type, the Relative Clause as a whole must express a property of CQs, that is, a property of propositions. But the entire NP must pick an IC, since it has to combine with rise. Once we have propositions, it is not clear how to turn them back into ICs to derive (56) and the variant of Gupta’s syllogism (33).

In Romero's account, the problem can be circumvented if we allow for the relative pronoun to abstract not over the complex [ANS+IC], but just over a trace $t_{5,<\mathrm{se}}$ embedded under ANS, as in (57). This means that the Relative Clause will express a property of individual concepts and not of propositions (or of propositional concepts). Thus, the compositional semantics of the NP will remain -except for the part in (58)- as in (24), the extension of the entire NP will be the

\footnotetext{
${ }^{10}$ The shifter in (54) has been modified from Nathan's (2005:94) original derivation to better match reading $B$.
} 
individual concept $\underline{\underline{\mathrm{x}}}<\mathrm{s, \textrm {e }}>\left[\mathrm{price}(\underline{\mathrm{x}}, \mathrm{w}) \& \forall \mathrm{w}\right.$ ” $\in \operatorname{Dox}_{\mathrm{f}}(\mathrm{w})[\underline{\mathrm{x}}(\mathrm{w}$ ”) $=\underline{\mathrm{x}}(\mathrm{w})]]$, and [[rise]] will take this individual concept as its argument. The price [ that ${ }_{5}$ Fred knows [ANS $\left.t_{5,<\mathrm{se}}\right]$ ] is rising.



\section{Conclusions and Open Questions}

Three main approaches to concealed question NPs have been evaluated with respect to several sets of data. The tentative results are summarized in table (59):

\begin{tabular}{|l|c|c|c|c|c|}
\hline & Basic CQ & Coord. & $\begin{array}{c}\text { A/B } \\
\text { ambiguity }\end{array}$ & $\begin{array}{c}\text { Gupta's } \\
\text { syllogism }\end{array}$ & $\begin{array}{c}\text { Head } \\
\text { Noun }\end{array}$ \\
\hline Pragmatic account & $*$ & $*$ & $*$ & ----- & ----- \\
\hline $\begin{array}{l}\text { Individual concept } \\
\text { account }\end{array}$ & 3 & $*$ & 3 & 3 & ??? \\
\hline $\begin{array}{l}\text { Propositional account } \\
\text { in Romero (2005b) }\end{array}$ & 3 & 3 & 3 & 3 & ??? \\
\hline $\begin{array}{l}\text { Propositional account } \\
\text { in Nathan (2005) }\end{array}$ & 3 & 3 & ??? & ??? & 3 \\
\hline
\end{tabular}

Many important questions on CQs with know and ICs with rise / fall / change remain open. I will briefly mention three here.

First, as noted in Nathan (2005:85ff), relational ICs with change have slightly different semantics from non-relational ICs. This is illustrated by the contrast in the truth conditions of (60) and (61). If the set of individual governors stayed the same but all the governors switched states, (60) is judged true. In contrast, if the set of pictures on Jordan's wall stayed the same but all the pictures changed positions, (61) is judged false. Can this difference in truth conditions in the IC domain somehow derive to the difference in grammaticality between relational and non-relational nouns in the CQ domain?

This year, every New England governor changed. 
(61) This week, every picture in Jordan's wall changed.

Second, ungrammatical CQs with non-relational nouns turn grammatical when certain types of modification are added (superlatives, Relative Clauses, post-nominal adjectives, etc.). This is illustrated in (62)-(63). It needs to be studied why these modifications yield such effect.

(62) a. \# Tell me USNDH's semanticist.

(Nathan 2005:97)

b. Tell me the semanticist who teaches at USNDH.

(63) a. \# Tell me Vermont's large city.

(Nathan 2005:97)

b. Tell me the largest city in Vermont / Vermont's largest city.

Third and finally, though several authors have studied which interrogative-taking predicates can embed CQs ( see Grimshaw 1979, Dor 1993, Nathan 2005), there is, to my knowledge, no clear crosslinguistic pattern. Verbs combining with propostions -like know, guess, announce, etc.- can embed a wide variety of CQs in languages with productive CQs. Verbs combining with question meanings -like ask and depend- allow for a limited number of CQs in English, as in (64), but allow for a wide range of CQs in Spanish, as in (65).

(64) a. Sam knows the capital of Vermont / the city I visited last week.

b. Sam asked the capital of Vermont / \# the city I visited last week.

(Nathan 2005:120)

(65) Samuel me preguntó la capital de Vermont / la ciudad que Samuel to-me asked the capital of Vermont / the city that iba a visitar.

I-was-going to visit

'Samuel asked me the capital of Vermont / the city that I was gonna visit.'

\section{Appendix: ANS with definite and non-definite CQs (in Reading B) within the propositional approach}

Definite CQ can have strongly exhaustive and mention-some readings (Romero 2005b), as interrogatives clauses do (Groenendijk and Stokhof 1984, Heim 1994, Beck and Rullmann 1999). The corresponding ANS $_{\text {STR }}$ and ANS SOME $_{\text {Operators for }}$ reading $\mathrm{B}$ are defined and applied to example (66b) below.
a. I know what price(s) Fred knows / may know
b. I know the price(s) that Fred knows / may know. 


$$
\text { [[know]] } \quad=\lambda \mathrm{p}_{<\mathrm{s},<\mathrm{s}, \mathrm{t}>>} \lambda \mathrm{x}_{\mathrm{e}} \lambda \mathrm{w} . \forall \mathrm{w}^{\prime} \in \operatorname{Dox}_{\mathrm{x}}(\mathrm{w})\left[\mathrm{p}(\mathrm{w})\left(\mathrm{w}^{\prime}\right)=1\right]
$$

[[the price (s) that Fred knows $]=$ $\lambda \mathrm{w}^{*} . \sigma \underline{\mathrm{x}}<\mathrm{s}, \mathrm{e}>\left[\operatorname{price}\left(\underline{\mathrm{x}}, \mathrm{w}^{*}\right) \& \forall \mathrm{w}^{\prime \prime} \in \operatorname{Dox}_{\mathrm{f}}\left(\mathrm{w}^{*}\right)\left[\underline{\mathrm{x}}\left(\mathrm{w}^{\prime \prime}\right)=\underline{\mathrm{x}}\left(\mathrm{w}^{*}\right)\right]\right]$

$$
\operatorname{ANS}_{S T R}\left(\mathrm{y}_{<\mathrm{s},<s, e>>}\right)=\lambda \mathrm{w} \mathrm{w}^{\prime} \cdot \mathrm{y}\left(\mathrm{w}^{\prime}\right)=\mathrm{y}(\mathrm{w})
$$

[[I know ANS STR $_{\text {the }}$ price(s) that Fred knows $\left.]\right]=$ $\lambda \mathrm{w} . \forall \mathrm{w}^{\prime} \in \operatorname{Dox}_{\mathrm{I}}(\mathrm{w})\left[\sigma \underline{\mathrm{x}}<\mathrm{s}, \mathrm{e},\left[\operatorname{price}\left(\underline{\mathrm{x}}, \mathrm{w}^{\prime}\right) \& \forall \mathrm{w}^{\prime \prime} \in \operatorname{Dox}_{\mathrm{f}}\left(\mathrm{w}^{\prime}\right)\left[\underline{\mathrm{x}}\left(\mathrm{w}^{\prime \prime}\right)=\underline{\mathrm{x}}\left(\mathrm{w}^{\prime}\right)\right]\right]=\right.$ $\left.\sigma \underline{\mathrm{X}} \mathrm{ss}_{\mathrm{s}, \mathrm{e}}\left[\operatorname{price}(\underline{\mathrm{x}}, \mathrm{w}) \& \forall \mathrm{w}^{\prime \prime} \in \operatorname{Dox}_{\mathrm{f}}(\mathrm{w})\left[\underline{\mathrm{x}}\left(\mathrm{w}^{\prime \prime}\right)=\underline{\mathrm{x}}(\mathrm{w})\right]\right]\right]$

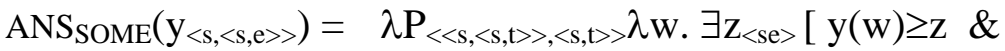

$$
\begin{aligned}
& \left.P\left(\lambda w^{\prime} \lambda w^{\prime \prime} \cdot y\left(w^{\prime \prime}\right) \geq z\right)(w)\right]
\end{aligned}
$$

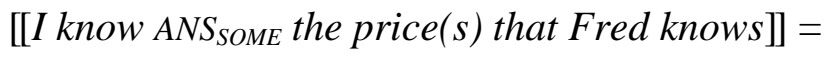
$\lambda \mathrm{w} . \exists \mathrm{z}_{<\mathrm{s}, \mathrm{e}>}\left[\sigma \underline{\mathrm{X}}_{\mathrm{s}, \mathrm{e},}\left[\operatorname{price}(\underline{\mathrm{x}}, \mathrm{w}) \& \forall \mathrm{w}^{\prime \prime} \in \operatorname{Dox}_{\mathrm{f}}(\mathrm{w})\left[\underline{\mathrm{x}}\left(\mathrm{w}^{\prime \prime}\right)=\underline{\mathrm{x}}(\mathrm{w})\right]\right] \geq \mathrm{z} \&\right.$ $\left.\forall \mathrm{w}^{\prime} \in \operatorname{Dox}_{\mathrm{I}}(\mathrm{w})\left[\sigma \underline{\mathrm{X}} \underline{s s, e}_{\mathrm{e}}\left[\operatorname{price}\left(\underline{\mathrm{x}}, \mathrm{w}^{\prime}\right) \& \forall \mathrm{w}^{\prime \prime} \in \operatorname{Dox}_{\mathrm{f}}\left(\mathrm{w}^{\prime}\right)\left[\underline{\mathrm{x}}\left(\mathrm{w}^{\prime \prime}\right)=\underline{\mathrm{x}}\left(\mathrm{w}^{\prime}\right)\right]\right] \geq \mathrm{z}\right]\right]$

Non-definite CQs in reading B have only the mention-some reading, as in (73). To derive this reading, we would need another ANS operator, defined in (75), that would apply to the NP's $<<$ se,st $>$,st $>$ intension (74) to yield the final truth conditions in (76).

(73) John knows a price that Fred knows.

(74) $[$ a price that Fred knows $]=$ $\lambda \mathrm{Q}_{<\mathrm{se}, \mathrm{st}>} \lambda \mathrm{w} . \exists \mathrm{x}_{<\mathrm{se}>}\left[\operatorname{price}(\mathrm{x}, \mathrm{w}) \wedge \forall \mathrm{w}^{\prime} \in \operatorname{Dox}_{\mathrm{f}}(\mathrm{w})\left[\mathrm{x}\left(\mathrm{w}^{\prime}\right)=\mathrm{x}(\mathrm{w})\right] \wedge \mathrm{Q}(\mathrm{x})(\mathrm{w})\right]$

(75) $\operatorname{ANS}_{\mathrm{SOME}}\left(\mathrm{R}_{<<\mathrm{se}, \mathrm{st}>\mathrm{st}>}\right)=$

$$
\begin{aligned}
& \lambda \mathrm{P}_{\langle<\mathrm{s},<\mathrm{s}, \mathrm{t}>><<\mathrm{s}, \mathrm{t}>>} \lambda \mathrm{w} . \exists \mathrm{z}_{<\mathrm{se}>}\left[\mathrm{R}\left(\lambda \mathrm{x}_{<\mathrm{se}>} \lambda \mathrm{w}^{*} . \mathrm{x}=\mathrm{z}\right)(\mathrm{w}) \wedge\right. \\
& \left.\left.\mathrm{P}\left(\lambda \mathrm{w}^{\prime} \lambda \mathrm{w}^{\prime \prime} \cdot \mathrm{R}\left(\lambda \mathrm{x}_{<\mathrm{se}}\right\rangle \mathrm{w}^{*} \cdot \mathrm{x}=\mathrm{z}\right)\left(\mathrm{w}^{\prime \prime}\right)\right)(\mathrm{w})\right]
\end{aligned}
$$

(76) $[$ I know a price that Fred knows $\rrbracket=$ $\lambda \mathrm{w} . \exists \mathrm{z}_{<\mathrm{se}>}\left[\exists \mathrm{x}_{<\mathrm{se}}>\left[\operatorname{price}(\mathrm{x}, \mathrm{w}) \wedge \forall \mathrm{w}^{\prime} \in \operatorname{Dox}_{\mathrm{f}}(\mathrm{w})\left[\mathrm{x}\left(\mathrm{w}^{\prime}\right)=\mathrm{x}(\mathrm{w})\right] \wedge \mathrm{x}=\mathrm{z}\right] \wedge\right.$ $\forall w^{\prime \prime} \in \operatorname{Dox}_{j}(w)\left[\exists x^{\prime}<\right.$ se $>\left[\right.$ price $\left(x^{\prime}, w^{\prime \prime}\right) \wedge \forall w^{\prime} \in \operatorname{Dox}_{\mathrm{f}}\left(w^{\prime \prime}\right)\left[x^{\prime}\left(w^{\prime}\right)=x^{\prime}\left(w^{\prime \prime}\right)\right]$ $\left.\left.\left.\wedge \mathrm{x}^{\prime}=\mathrm{z}\right]\right]\right]$

\section{References}

Beck, Sigrid and Hotze Rullmann: 1999, 'A flexible approach to exhaustivity in questions', Natural Language Semantics 7, 249-298.

Cresswell, Max: 1990, Entities and Indices, Dordrecht, Kluwer.

Dor, Daniel: 1993, 'Towards a Semantic Account of Concealed Questions', in M. Bernstein (ed.) Proceedings of ESCOL '92, pp. 56-67. 
Dowty, David R., Robert E. Wall and Stanley Peters: 1981, Introduction to Montague Semantics, Dordrecht, Reidel.

Farkas, Donka: 1993, 'Modal anchoring and NP scope', Linguistics Research Center working paper LRC-93-08, UC Santa Cruz.

Frana, Ilaria: 2006, 'The de re analysis of concealed questions. A unified approach to definite and indefinite concealed questions', this volume.

Gallin, Daniel: 1975, Intensional and Higher-Order Modal Logic with Applications to Montague Semantics, Amsterdam, North-Holland.

Grimshaw, Jane: 1979, 'Complement selection and the lexicon', Linguistic Inquiry 10, 279-326.

Groenendijk, Jeroen and Martin Stokhof: 1984, Studies on the Semantics of Questions and the Pragmatics of Answers. Doctoral Dissertation, University of Amsterdam.

Heim, Irene: 1979, 'Concealed Questions', in R. Bäuerle, U. Egli and A. von Stechow (eds.) Semantics from different points of view, Berlin, Springer.

Heim, Irene: 1994, 'Interrogative Semantics and Karttunen's Semantics for know', in R. Buchalla and A. Mittwoch (eds.) Proceedings of the Israeli Association for Theoretical Linguistics I, Jerusalem.

Heim, Irene and Angelika Kratzer: 1998, Semantics in Generative Grammar, Blackwell.

Janssen, Theo M.V.: 1984, 'Individual concepts are useful', in F. Landman and F. Veltman (eds.) Proceedings of the $4^{\text {th }}$ Amsterdam Colloquium, Foris.

Kratzer, Angelika: 2002, 'Facts: Particulars or Information Units?', Linguistics and Philosophy 25, 655-670.

Lasersohn, Peter: 2005, 'The temperature paradox as evidence for a presuppositional analysis of definite descriptions', Linguistic Inquiry 36, 127-134.

Löbner, Sebastian: 1981, Intensionale Verben und Funktionalbegriffe, Doctoral Dissertation, University of Tübingen.

Montague, Richard: 1974, 'The proper treatment of quantification in ordinary English', in R. H. Thomason (ed.) Formal Philosophy: Selected papers by Richard Montague, New Haven, Yale University Press.

Nathan, Lance: 2005, On the interpretation of concealed questions, Doctoral Dissertation (draft), MIT. [Page references are to the draft version.]

Percus, Orin: 2000, 'Constraints on some other variables in syntax', Natural Language Semantics 8, 173-229.

Romero, Maribel: 2004, 'Intensional Noun Phrases with know and be', Catalan Journal of Linguistics 3, 147-178.

Romero, Maribel: 2005a: 'Concealed Questions and Specificational Subjects', Linguistics and Philosophy 28, 687-737.

Romero, Maribel: 2005b, 'Connectivity in a Unified Analysis of Specificational Subjects and Concealed Questions', ms. UPenn. To appear in P. Jacobson and C. Barker (eds.), Direct Compositionality. 